Luiz Vilela - Paul Melo e Castro

\title{
No More Indians
}

"More liquor," said the dark-skinned man holding out his glass.

"No more liquor," said the fat man grabbing the bottle from the counter. "Indian dance now; liquor later."

"Liquor," said the dark-skinned man stretching for the bottle.

"Afterwards," said the fat man, shielding the bottle behind his vast bulk. "Now Indian dance." He waggled his hips and his flabby belly shook. "Now Indian dance out front. Everyone watch Indian dancing."

The dark-skinned man stopped and stared at his fat counterpart, stared at him as a famished, skittish dog might at a person chewing a sandwich in a roadside bar. The fat man waggled his hips once more, his arms upraised, the bottle in one hand and a shot glass he was drinking from in the other. The dark-skinned man chuckled.

"You like that, eh?" said the fat man. His flabby jowls wobbled with laughter, his eyes vanishing between puffy little lids. "Off you go, Indian. Bwana want to see Indian dance. Me bwana, you Indian, monkey."

"Not monkey." The Indian shook his head.

"Gorilla," said the fat man, guffawing again.

"Not gorilla; Indian."

"Chimpanzee."

"Not chimpanzee: Indian. Indian."

"Orang-utan."

"Indian." The dark-skinned man beat his chest. "Indian." 
The fat man choked with laughter. He quivered like jelly, breathless and red-faced, tears streaming down his cheeks. "Ah, I can't take any more. I've had it. This Indian'll be the death of me."

"Liquor now," said the dark-skinned man.

"What do you mean liquor now, you cheeky bastard," said the fat man, raising his voice and puffing out his chest. "Go dance first. Go and dance out front, then you'll get liquor, lots of liquor, see..." and he lifted his arm up high to display the bottle of liquor.

The dark-skinned man shuffled his feet and jigged awkwardly before his fat counterpart.

"Bloody hell," said the fat man with another snicker. He turned to his companions at the nearby tables: "Did you see that? Indigenous samba. No, this Indian'll be the death of me... I've never seen..." He turned back to the dark-skinned man: "Chop chop. To the front, so everyone can see you. Dance first, liquor later."

The dark-skinned man obeyed. Swaying slightly, he trudged out to the front, the space between the tables and the counter.

"And look smart about it!" yelled the fat man.

The dark-skinned man began to perform the uncoordinated, graceless moves of what was supposedly a dance, flinging his hands in the air and stamping his feet. The fat man shook with laughter. Almost everyone around him was laughing.

"More! More!" shouted the fat man as he clapped.

Spurred on by the cries and the heat generated by his own moves, the dark-skinned man worked himself up into a frenzy, before losing his balance and whirling round to fall flat on his backside. The fat man laughed so hard he had to prop himself up against the counter.

The dark-skinned man sat on the floor with a dopey expression on his face, as if he hadn't yet understood what was happening to him, and looked round at the audience who were in stitches. The fat man came up to him and, leaning down, showed him the bottle. When the Indian tried to grab it, he just snatched it away and sniggered. The dark-skinned man crawled along with his right arm outstretched as the fat man backed away saying, "Here boy, here boy, here boy..." 
A man standing at the far end of the counter gestured to the barman, who was also watching the show with an air of suppressed mirth.

"How much do I owe?"

"Four savouries and two soft drinks? Twenty-six."

The man took out his wallet, removed the money and paid. He took the hand of the boy with him.

"Let's go."

Before leaving, he took one last glance at the show unfolding in the middle of the room. The darkskinned man had managed to get hold of the bottle. He necked its contents as the fat man watched on and laughed.

Outside it was dark. A moonless night. The pair got into the Beetle. The car took a bend onto the slip road before reaching the motorway. They drove for a while in silence.

"Tired?" asked the man.

The boy shook his head.

They drove on for a while longer. It was Sunday and there was lots of traffic.

"Dad," said the boy.

"What?"

"Why was that fat man calling the other man an Indian?"

"Because he was an Indian."

"He's an Indian?"

The man nodded, his eyes on the road ahead.

"A real Indian, Dad?"

"A real Indian."

"But why was he wearing clothes then?"

"He was a civilised Indian." 
"What's a civilised Indian?"

“It's an Indian who's not an Indian anymore."

"He's not an Indian anymore?"

His father didn't answer. He was watching the petrol tanker in front, waiting for the right moment to overtake. The chance came and he took it, speeding into a clear stretch of road.

"Dad, doesn't he have a loincloth now?"

"Loincloth?" The father turned to his boy.

"The Indian, Dad."

"Ah."

"Doesn't he have a loincloth now?"

"Probably not."

"What about arrows?"

"Probably not."

"Why do you say 'probably'?"

"Because I'm not sure, and when you're not sure, you say 'probably'. Got it?"

"Probably."

His father laughed and tousled his hair.

"Tuberculosis."

"Phenomenal."

"Tsunami."

"Bacillus."

"Englebert."

"Not Engelbert, Dad. You promised you wouldn't use that one anymore."

"Engelhelm then." 
"Engelhelm?" The boy laughed. "Who's Engelhelm?"

"Engelbert's brother."

"Oh, Dad," the boy groaned.

His father's attention returned to the road. There was a long, slightly risky curve. They both sat in silence, watching the cars ahead.

"Dad, why's the Indian not an Indian anymore? Does he not want to be an Indian?"

“I don't know, son. I don't think so. Indians like being Indians. They like doing the things Indians do. They like to wander about in loincloths, or naked, they like to hunt and fish and all the rest. Just like you when you're on the farm. Don't you like to swim in the stream, climb trees, play in the mud?" "Yup."

"There you go. Indians like doing those things too."

"So why's that Indian not an Indian anymore?"

"Because that's what the others wanted."

"What others?"

"The others. The whites. The civilised men..."

"You too, Dad?"

"Think your father would want something like that?"

The boy was thoughtful for a moment and didn't answer.

"It's because that's what they wanted, for the Indian not to be an Indian anymore."

"That's civilisation for you."

"What's civilisation?"

"Civilisation? A crock of shit."

The boy laughed.

"Dad, can I tell you something? Can I?" 
"Go on then."

"I like it when you swear."

The father laughed and glanced at his son.

"Elephant fart."

"Horse piss," the boy shot back.

They both laughed.

"Dad, why doesn't Mum swear or like it when I do?"

"Because your mother is civilised."

"What about you?"

“I'm not. I'm an Indian."

"What about me? What am I?"

"You're an Indian too. A little Indian."

"What about the fat man?"

"What fat man?"

"The fat man from the bar, Dad."

"Ah."

"He's civilised, isn't he?"

"The fat man? Oh..." The father chuckled. "He's civilisation itself. The most civilised man on earth."

"Who else is an Indian?"

“Who else? There aren't many Indians. Fewer by the day. Soon there won't be any left at all."

"No more Indians, Dad?"

His father didn't answer. The boy stared at him anxiously.

"Hey, Dad: no more Indians?" 
His father nodded slowly. He was staring straight ahead. But not at the road, the boy knew. He knew too that when his father was like that, he didn't like people to keep on at him.

So he fell silent too. He imagined a world in which there were no more Indians, a world in which there were no more Indians to be seen and no one ever mentioned Indians because there weren't any left. He couldn't really grasp how it would be but felt somehow that if that ever happened, it would be a terrible, sad thing - as terrible and sad as losing your mother.

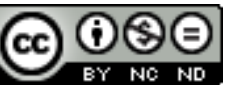

Creative Commons Attribution-NonCommercial-NoDerivatives 4.0 International License 